\title{
EFEKTIVITAS ART THERAPY SEBAGAI KATARSIS UNTUK MENGURANGI TINGKAT KECEMASAN AKADEMIK PADA REMAJA
}

\section{Gusti Ayu Nyoman Triana Dewi, Tatik Meiyutariningsih}

Program Studi Magister Profesi Psikologi, Universitas 17 Agustus 1945 Surabaya, Indonesia

Email: gustiayudewi882@gmail.com, tatikmeiyun@untag-sby.ac.id

\section{Abstrak}

Remaja memiliki masalah emosi yang berbeda-beda dan cara menyikapi permasalahan sesuai dengan karakteristik kepribadian masing-masing. Individu yang memiliki karakteristik introvert cenderung menyimpan setiap permasalahannya, sehingga menimbulkan berbagai dampak. Salah satu dampaknya adalah mengalami kecemasan baik dalam akademik maupun lainnya. Praktikan membantu melakukan katarsis dengan terapi menggambar dan memberikan psikoedukasi untuk keluarga klien. Metode penelitian ini menggunakan single subject design. Terdapat tiga fase yang dilakukan dalam melalukan intervensi, yaitu fase base line dalam menentukan perilaku yang akan di intervensi, fase intervensi dan terakhir fase baseline evaluasi. Teknik pengumpulan data yang digunakan peneliti dalam penelitian ini adalah metode wawancara (autoanamnesa dan alloanamnesa), observasi, dan tes psikologi yaitu WAIS dan Grafis. Peneliti menggunakan Kuesioner TMAS (Taylor Manifest Anxiety Scale) untuk mengukur tingkat kecemasan sebelum dan sesudah pemberian terapi. Klien dalam penelitian ini adalah remaja perempuan berusia 14 tahun yang mengalami gangguan kecemasan. Intervensi atau terapi dilakukan selama 9 hari, setiap harinya terapi dilakukan selama 3 jam. Hasil intervensi yang dilakukan menunjukan perubahan perilaku sebelum dan sesudah diberikan intervensi. Sebelum intervensi klien selalu memendam masalahnya sendiri, ia kurang dapat mengungkapkan apa yang ia rasakan dan inginkan, sehingga masalah tersebut menumpuk dan keluar dalam bentuk kecemasan terutama yang tampak adalah kecemasan akademik. Setelah melakukan intervensi klien menjadi lebih tenang ketika akan menghadapi ujian atau atau pelajaran disekolahnya dan klien menyadari bahwa bercerita/berkomunikasi dengan orang lain dapat meringankan beban dipikirannya.

Kata Kunci: kecemasan akademik; art therapy; psikoedukasi keluarga

\section{Abstract}

Emotional issues among adolescents quite vary and their attitude in dealing with such issues are determined by their personalities. Introverted individuals tend to keep the issues for themselves which might bring some negative impacts, one of which is the tendency to experience anxiety disorders, including academic anxiety. Therapists often use drawing therapy as catharsis, while psychoeducation is performed to clients' families. This research was conducted in a single-subject design. There are mainly three phases in performing intervention including base

$\begin{array}{ll}\text { How to cite: } & \text { Dewi.G.A.N.T \& Meiyutariningsih, T. (2021) Efektivitas Art Therapy Sebagai Katarsis untuk Mengurangi } \\ & \text { Tingkat Kecemasan Akademik pada Remaja. Syntax Literate: Jurnal Ilmiah Indonesia, } 6(10) . \\ & \text { http://dx.doi.org/10.36418/ Syntax-Literate.v6i10.4263 } \\ \text { E-ISSN: } & \text { 2548-1398 } \\ \text { Published by: } & \text { Ridwan Institute }\end{array}$


line phase, in which the attitude to be intervened is determined, intervention phase, and evaluation baseline phase. In this research, data were collected through interview (autoanamnesa and alloanamnesa), observation, and psychological tests in the forms of WAIS and Graphics. The TMAS questionnaire (Taylor Manifest Anxiety Scale) was employed to measure client's anxiety levels before and after therapy. The client in this research was a 14 year-old female adolescent who had anxiety disorder. The intervention or therapy was performed every day within 9 days, each of which lasted for 3 hours. The outcome of the intervention showed the change in behaviour before and after the intervention. Before intervention, the client often kept her problems for herself, and she could not express her feeling and expectations. Eventually. problems were accumulated and appeared as anxiety, especially academic anxiety which was quite dominant. After the intervention, the client became calmer in facing school examinations or attending classes. The client also realized that sharing session with other people could help reducing the burden.

Keywords: academic anxiety; art therapy; psychoeducation for family

Received: 2021-09-20; Accepted: 2021-10-05; Published: 2021-10-20

\section{Pendahuluan}

Remaja seringkali mengalami permasalahan emosional seperti cepat marah, mudah tersinggung, trauma, dan sebagainya. Cara menyikapi permasalahan yang dihadapi juga sesuai dengan karakteristik kepribadian masing-masing. Ada beberapa pribadi yang mampu menyampaikan emosi atau keluhannya secara langsung sehingga tidak menjadi beban, namun ada pula remaja yang kurang dapat menyampaikan apa yang ia rasakan secara langsung. Remaja yang tidak dapat menyampaikan apa yang sedang dirasakan akan menimbulkan berbagai dampak, salah satunya adalah mengalami kecemasan baik dalam bidang akademik atau lainnya.

Kecemasan merupakan emosi yang tidak menyenangkan yang dapat menimbulkan gejala seperti perasaan khawatir dan rasa takut (Annisa \& Ifdil, 2016) Atkinson, dkk (Blackburn, Davidson, \& Kendell, 1994) menambahkan bahwa proses terjadinya kecemasan bermula ketika individu bertemu dengan suatu stimulus yang dirasakan dapat memberikan ancaman. Kecemasan akademik sendiri merupakan jenis kecemasan yang berkaitan dengan bahaya akan datang dari lingkungan lembaga akademik termasuk pengajar dan mata pelajaran yang ataupun mata kuliah tertentu. Hal tersebut merupakan perasaan mental gelisah atau distress sebagai reaksi terhadap situasi di lembaga akademik yang dianggap negatif (Attri, 2013).

Salah satu intervensi yang dapat digunakan untuk mengatasi permasalah tersebut adalah Art Therapy. Menurut The American Art Therapy Association (Sholihah, 2018) art therapy adalah sebuah proses penyembuhan yang dilakukan dengan membuat sebuah karya seni yang kreatif. Proses penyembuhan ini berguna dalam meningkatkan kualitas kehidupan. Art therapy sangat membantu dalam mengatasi gangguan emosi, menyelesaikan konflik, menambah wawasan, mengurangi perilaku bermasalah, serta meningkatkan kebahagiaan hidup. Bagi banyak individu, seni merupakan sarana paling 
mudah sebagai pernyataan pribadi, sehingga dapat digunakan sebagai fokus dalam proses terapeutik (Case \& Dalley, 2002; Hughes, 2009; Wu et al., 2009). Oleh karena itu, hasil karya seni juga mampu digunakan sebagai bentuk asosiasi bebas sebagai bentuk proyeksi atas permasalahan yang tidak disadarinya (unconscious). Maka tugas seorang terapis adalah mengajak pasien untuk menceritakan secara bebas dari hasil karya seni yang dibuatnya dan menggalinya secara mendalam atas permasalahan yang dihadapinya tersebut (Case \& Dalley, 2002) dengan demikian Art Therapy merupakan proses terapi yang memiliki efektifitas tinggi dalam menurunkan gangguan psikologis. Seperti halnya jenis terapi lainnya, Art Therapy dapat digunakan dengan intensif ataupun jangka waktu panjang (Gussak, 2009) dalam (Mukhlis, 2011). Hal tersebut disesuaikan dengan kepentingan dan tujuan penelitian. Waktu yang dibutuhkan dalam proses terapi jangka panjang biasanya berkisar antara 3 bulan sampai 1 tahun (Gussak, 2009; Huss, Scott, Stuck, Trotter, \& Egger, 2009; Wallin \& Durr, 2002). Sedangkan untuk terapi dalam jangka pendek biasanya dilakukan tidak lebih dari 12 sesi (Dinie, 2016; Malchiodi, 2014).

Terapi menggambar berkembang untuk membantu anak yang tidak dapat mengekspresikan pikiran dan perasaan melalui kata-kata. Gambar dapat memberikan makna jika dihubungkan dengan anak-anak yang terluka, mengasingkan diri, kecewa, dan tidak dapat mengungkapkan pikiran dan perasaan kepada orang lain (Wuryani, 2016).

(Edwards, 2014) menjelaskan bahwa pada dasarnya Art Therapy tidak memiliki prosedur khusus dalam pelaksanaannya. Namun secara khusus terdapat tiga tahapan yang banyak digunakan dalam Art Therapy, yaitu mengarahkan fokus objek, Subjek membuat sebuah gambar yang merepresentasikan peristiwa atau perasaan pada tahap pertama dan representasi gambar oleh terapis (Edwards, 2014) Pada tahap pertama terapis menjelaskan atau memberikan materi yang berhubungan dengan peristiwa atau perasaan Subjek. Tugas Subjek pada tahap ini adalah memikirkan dan merasakan topik serta kejadian yang diberikan oleh terapis.

Tahap kedua, terapis melakukan observasi terhadap proses Subjek mengerjakan sebuah gambar dan memberikan dukungan serta reinforcement atas usaha Subjek. Pada tahap terakhir, terapis memperhatikan arti atau makna kreasi klien dengan memperhatikan emosi pada gambar melalui ide gambar, penggunaan warna, proporsi, tekanan, dan desai secara keseluruhan serta asosiasi bebas verbal klien. Pada tahapan ini, terapis juga perlu menggali lebih lanjut tentang simbol dan gambar yang ada maupun yang tidak ada dalam kreasi klien. Proses tersebut kemudian disempurnakan dengan kerjasama terapis, subjek, dan profesi lain untuk memproses secara verbal dan menggunakannya untuk membantu Subjek menyadari dan memahami dirinya.

Selain art therapy, dalam upaya menurunkan kecemasan akademik pada klien juga diberikan psikoedukasi keluarga dengan tujuan agar orang tua lebih tenang dalam menghadapi situasi serta mengetahui, menyadari kondisi klien dan apa yang diperlukan klien saat ini, sehingga dapat memberikan sikap yang tepat untuk menghadapi klien. Dukungan sosial yang paling baik untuk siswa yang mengalami kecemasan akademik 
yaitu yang berasal dari keluarga dalam hal ini yaitu orang tua (Ernawati \& Rusmawati, 2015). House (Puspitasari, 2013) juga menjelaskan dukungan sosial sebagai persepsi seseorang terhadap dukungan potensial yang diterima dari lingkungan, dukungan sosial tersebut mengacu pada kesenangan yang dirasakan sebagai penghargaan akan kepedulian serta pemberian bantuan dalam konteks hubungan yang akrab.

Berdasarkan hasil penelitian yang dilakukan (Siswoyo, Setioputro, \& Albarizi, 2016) dalam jurnal (Psychoeducation Therapy Reduces Family Anxiety In Treating Family Member Who Suffers From Cataract) menyatakan bahwa Terapi psikoedukasi keluarga dapat membantu mengurangi kecemasan sehingga keluarga dapat mencari solusi bagi anggota keluarga yang menderita katarak dengan tepat. Hasil penelitian tersebut menunjukan bahwa psikoedukasi keluarga sangat penting diberikan pada anggota keluarga sehingga anggota keluarga dapat mencari solusi yang tepat.

\section{Metode Penelitian}

Metode penelitian ini menggunakan desain kasus tunggal dengan pemberian art therapy dan psikoedukasi keluarga. Klien dalam penelitian ini adalah remaja perempuan berusia 14 tahun yang mengalami gangguan kecemasan. Sesuai dengan penelitian (Adriani \& Satiadarma, 2011) remaja yang didiagnosis menderita leukemia mengalami beberapa reaksi emosional yang menyertainya, salah satunya adalah kecemasan. Art therapy disini digunakan untuk mengurangi kecemasan pada remaja penderita leukemia.

Desain kasus tunggal (single case design) terdiri dari tiga tahap. Tahap awal yaitu fase baseline adalah menentukan target atau perilaku yang akan di intervensi menggunakan metode wawancara (autoanamnesa dan alloanamnesa), observasi dan tes psikologi yaitu WAIS (Wechsler Adult Intelligence Scale) dan Tes Grafis (BAUM, DAP, dan HTP) dalam mengumpulkan datanya. Peneliti juga menggunakan Kuesioner TMAS (Taylor Manifest Anxiety Scale) untuk mengukur tingkat kecemasan sebelum dan sesudah pemberian terapi. Data yang telah dikumpulkan peneliti akan menjadi dasar dalam membuat diagnosa dan menentukan intervensi yang tepat untuk subjek.

Kemudian, tahap kedua fase intervensi yaitu, pemberian treatment dimana penerapan tehnik intervensi dilakukan. Treatment atau terapi yang berikan adalah art therapy dan psikoedukasi keluarga, tahap pelksanaan digambarkan dalam tabel dibawah ini.

\section{Tabel 1}

\section{Pelaksanaan intervensi atau terapi}

\begin{tabular}{lll}
\hline \multicolumn{1}{c}{ Waktu } & Kegiatan & \multicolumn{2}{c}{ Aktivitas } \\
\hline Intervensi & Sesi 1 : 2 & 1. Melakukan pendekatan pada klien agar ia percaya, \\
hari 1 & Jam & nyaman dan terbuka dalam menceritakan yang ada \\
& -Membangun & dalam pikirannya pada praktikan selama proses \\
& rapport & intervensi. \\
& -Melakukan & 2. Menanyakan pada klien hal-hal yang ia sukai, teknik \\
& kontrak & $\begin{array}{l}\text { apa yang sering digunakan untuk menggambar, jenis- } \\
\text { terapi dan }\end{array}$ \\
& jenis gambar apa saja yang klien sukai dan yang paling \\
& berapa lama & sering ia gambar. \\
\hline
\end{tabular}




\begin{tabular}{|c|c|c|}
\hline & $\begin{array}{lr}\text { waktu dalam } \\
\text { satu sesi } \\
\text { terapi. }\end{array}$ & \\
\hline $\begin{array}{l}\text { Intervensi } \\
\text { hari II, III }\end{array}$ & $\begin{array}{l}\text { Art therapy : } \\
\text { 3 Jam }\end{array}$ & $\begin{array}{l}\text { 1. Mengintrusikan klien untuk menuangkan apa saja yang } \\
\text { sedang ia pikirkan sekarang atau yang ia inginkan dalam } \\
\text { bentuk gambar. } \\
\text { 2. Memberikan reinforcement saat proses terapi dalam } \\
\text { bentuk sosial reward. Selesai menggambar praktikan } \\
\text { melakukan probing terhadap hasil gambarnya. } \\
\text { 3. Selesai proses terapi praktikan memberikan reward } \\
\text { berupa perlengkapan gambar }\end{array}$ \\
\hline $\begin{array}{l}\text { Intervensi } \\
\text { hari IV }\end{array}$ & $\begin{array}{l}\text { Sesi I } \\
\text { Psikoedukasi } \\
\text { Keluarga : } 2 \\
\text { Jam }\end{array}$ & $\begin{array}{l}\text { Psikoedukasi Keluarga } \\
\text { (tanpa diketahui klien ) } \\
\text { 1. Menunjukan dan menjelaskan hasil gambar klien pada } \\
\text { orang tua. } \\
\text { 2. Mengajak orang tua klien berdiskusi dan memberi } \\
\text { psikoedukasi mengenai dampak yang klien alami jika } \\
\text { orang tua terus memaksakan kehendaknya. } \\
\text { 3. Serta mengajak orang tua mencari solusi agar klien } \\
\text { tidak tertekan dan dapat terbuka dalam menyampaikan } \\
\text { apa yang ia rasakan dan inginkan. } \\
\text { 4. Mengintrusikan klien untuk menuangkan apa saja yang } \\
\text { sedang ia pikirkan sekarang atau yang ia inginkan } \\
\text { dalam bentuk gambar. }\end{array}$ \\
\hline & $\begin{array}{l}\text { Sesi } 2 \\
\text { Art Therapy } \\
\text { : 3 Jam }\end{array}$ & $\begin{array}{l}\text { 1. Mengintrusikan klien untuk menuangkan apa saja yang } \\
\text { sedang ia pikirkan sekarang atau yang ia inginkan dalam } \\
\text { bentuk gambar. } \\
\text { 2. Memberikan reinforcement saat proses terapi dalam } \\
\text { bentuk sosial reward. Selesai menggambar praktikan } \\
\text { melakukan probing terhadap hasil gambarnya. } \\
\text { 3. Selesai proses terapi ayah klien memberikan reward } \\
\text { berupa perlengkapan gambar }\end{array}$ \\
\hline $\begin{array}{l}\text { Intervensi } \\
\text { hari V,VI } \\
\text { dan VII }\end{array}$ & $\begin{array}{l}\text { Art Therapy } \\
\text { : } 3 \text { Jam }\end{array}$ & $\begin{array}{l}\text { 1. Mengintrusikan klien untuk menuangkan apa saja yang } \\
\text { sedang ia pikirkan sekarang atau yang ia inginkan dalam } \\
\text { bentuk gambar. } \\
\text { 2. Memberikan reinforcement saat proses terapi dalam } \\
\text { bentuk sosial reward. Selesai menggambar praktikan } \\
\text { melakukan probing terhadap hasil gambarnya. } \\
\text { 3. Selesai proses terapi ayah klien memberikan reward } \\
\text { berupa perlengkapan gambar }\end{array}$ \\
\hline $\begin{array}{l}\text { Intervensi } \\
\text { hari VIII }\end{array}$ & $\begin{array}{l}\text { Sesi I } \\
\text { Art Therapy } \\
\text { : } 3 \text { Jam }\end{array}$ & $\begin{array}{l}\text { 1. Mengintrusikan klien untuk menuangkan apa saja yang } \\
\text { sedang ia pikirkan sekarang atau yang ia inginkan } \\
\text { dalam bentuk gambar. } \\
\text { 2. Memberikan reinforcement saat proses terapi dalam } \\
\text { bentuk sosial reward. Selesai menggambar praktikan } \\
\text { melakukan probing terhadap hasil gambarnya. } \\
\text { 3. Selesai proses terapi ayah dan ibu klien memberikan } \\
\text { reward berupa peralatan menggambar }\end{array}$ \\
\hline
\end{tabular}




\begin{tabular}{|c|c|c|}
\hline & $\begin{array}{l}\text { Sesi II } \\
\text { Psikoedukas } \\
\text { i Keluarga : } \\
2 \text { Jam }\end{array}$ & $\begin{array}{l}\text { 1. Menunjukan dan menjelaskan hasil gambar klien secara } \\
\text { keseluruhan pada orang tua. } \\
\text { 2. Menginformasikan pada orang tua hasil sementara dan } \\
\text { kondisi klien dari proses intervensi yang telah } \\
\text { dilakukan. } \\
\text { 3. Mengajak orang tua mempertahankan sikap dan tidak } \\
\text { memaksakan apa yang kurang disukai anak. }\end{array}$ \\
\hline $\begin{array}{l}\text { Intervensi } \\
\text { hari IX }\end{array}$ & $\begin{array}{l}\text { Terminasi : } \\
\text { 2 Jam }\end{array}$ & $\begin{array}{l}\text { Praktikan menanyakan perbedaan kondisi klien sebelum } \\
\text { dan sesudah intervensi serta praktikan membuat } \\
\text { kesimpulan dari intervensi yang dilakukan selama ini. }\end{array}$ \\
\hline
\end{tabular}

Secara keseluruhan terapi dilakukan selama 9 hari dan terdiri dari tiga tahap, yaitu:

1. Tahap pertama yang dilakukan adalah pembangunan rapport dan melakukan kontrak terapi. Tahap pertama dilakukan selama 2 jam dalam satu kali pertemuan atau satu sesi, tujuannya klien mampu bertanggung jawab dan konsisten dengan apa yang telah disepakati sehingga perilaku perilaku dapat berubah sesuai dengan yang diharapkan.

2. Tahap kedua dilakukan selama 7 hari dan setiap harinya klien akan melakukan terapi selama 3 jam. Pada tahap ini klien melakukan terapi melukis/menggambar tujuannya klien lebih nyaman dalam menceritakan masalah ataupun keluhan yang ia rasakan sehingga dapat mengurangi beban yang ia pendam selama ini. Serta dilakukan psikoedukasi keluarga pada pertemuan ke IV \& VIII, tujuannya orang tua mengetahui kondisi dan menyadari apa yang diperlukan klien saat ini, sehingga dapat memberikan sikap yang tepat untuk menghadapi klien.

3. Tahap terakhir adalah terminasi dari seluruh kegiatan yang dilakukan.

Setelah diberikan treatment atau terapi, fase terakhir adalah baseline evaluasi yang merupakan tindak lanjut dari tehnik intervensi. Tahap evaluasi ini untuk mengetahui faktor-faktor apa saja yang menghambat jalannya proses terapi yang dilakukan, serta melihat apakah klien dapat mempertahankan perilaku yang sudah diintervensi dengan baik. Peralatan yang diperlukan dalam proses intervensi art therapy yaitu : 1) buku gambar (A3), 2) Krayon oil pastel, 3) Pensil, 4) Penghapus dan 5) tissue. 


\section{Hasil dan Pembahasan}

\section{A. Hasil Penelitian}

Tabel 2

\begin{tabular}{|c|c|}
\hline \multicolumn{2}{|c|}{ Hasil TMAS (Taylor Manifest Anxiety Scale) } \\
\hline $\begin{array}{l}\text { Hasil TMAS sebelum } \\
\text { intervensi }\end{array}$ & $\begin{array}{l}\text { Hasil TMAS setelah } \\
\text { intervensi }\end{array}$ \\
\hline $\begin{array}{l}\text { Skor }>25 \text {, artinya klien } \\
\text { mengalami kecemasan } \\
\text { pada kaTegori berat }\end{array}$ & $\begin{array}{lr}\text { Skor }<20 & \text { Artinya klien } \\
\text { tidak } & \text { mengalami } \\
\text { kecemasan } & \text { yang } \\
\text { berlebihan } & \end{array}$ \\
\hline
\end{tabular}

Tabel 3

Hasil Intervensi

\begin{tabular}{|c|c|}
\hline Hasil Sebelum intervensi & Hasil Sesudah Intervensi \\
\hline $\begin{array}{l}\text { - Sebelum mendapatkan intervensi klien selalu } \\
\text { memendam masalahnya sendiri, ia kurang dapat } \\
\text { mengungkapkan apa yang ia rasakan dan } \\
\text { inginkan, sehingga masalah tersebut menumpuk } \\
\text { dan tidak terselesaikan.Masalah tersebut keluar } \\
\text { dalam bentuk emosi seperti rasa kahawatir yang } \\
\text { berlebih, nafsu makan menurun dan sering } \\
\text { menangis. } \\
\text { - Hal ini juga mempengaruhi aktivitas } \\
\text { akademiknya, ia menjadi sulit konsentrasi dan } \\
\text { mengalami ketakutan yang berlebihan. } \\
\text { - Klien tidak menyadari dampak yang terjadi ketika } \\
\text { ia terus menyimpan setiap masalah yang dialami, } \\
\text { ia juga tidak mengetahui cara menyampaikan isi } \\
\text { pikirannya pada orang lain. Klien sering marah } \\
\text { dan menangis saat menyampaikan isi pikirannya } \\
\text { sehingga orang lain salah paham. }\end{array}$ & $\begin{array}{l}\text { Setelah melakukan tahap-tahap intervensi } \\
\text { di atas, klien menjadi lebih tenang ketika } \\
\text { akan menghadapi ujian atau atau pelajaran } \\
\text { disekolahnya. Ia juga mulai menyadari } \\
\text { bahwa bercerita / berkomunikasi dengan } \\
\text { orang lain akan dapat meringankan beban } \\
\text { dipikirannya. Serta Klien mengetahui cara } \\
\text { berkomunikasi agar orang tidak salah } \\
\text { paham yaitu dengan menyampaikannya } \\
\text { dengan cara yang baik. }\end{array}$ \\
\hline
\end{tabular}

\section{B. Pembahasan}

Berdasarkan hasil intervensi yang dilakukan melalui metode art therapy dan psikoedukasi keluarga diperoleh hasil klien menjadi lebih terbuka untuk menyampaikan atau mengkomunikasikan apa yang ia rasakan baik melalui gambar maupun secara langsung, sehingga jika ada pembicaraan orang lain yang menggangu klien tidak hanya memendamnya. Cara tersebut efektif untuk mengurangi beban pikiran dan menurunkan kecemasan-kecemasan yang selama ini ia rasakan.

Penelitian-penelitian sebelumnya yang serupa dilakukan oleh (Muthmainnah, 2015) dalam jurnal "Peranan Terapi Menggambar Sebagai Katarsis Emosi Anak". Hasil yang di dapat adalah sebagian anak mengalami permasalahan namun belum memiliki kemampuan untuk mengungkapkan apa yang dialaminya secara lisan. Menggambar dapat dijadikan sebagai salah satu bentuk terapi untuk membantu anak 
mengungkapkan pikiran dan perasaan serta menyalurkan energi emosi dengan cara yang lebih aman.

Hasil penelitian yang dilakukan oleh (Muthmainnah, 2015) sejalan dengan hasil penelitian dari peneliti, dengan art therapy klien menjadi lebih terbuka untuk menyampaikan atau mengkomunikasikan apa yang ia rasakan baik melalui gambar maupun secara langsung. Cara tersebut efektif untuk mengurangi beban pikiran dan menurunkan kecemasan-kecemasan yang selama ini ia rasakan.

Penelitian serupa juga ada pada jurnal (Hasanat, 2016) "Buletin Psikologi Kajian Teoritis Pengaruh Art Therapy Dalam Mengurangi Kecemasan Pada Penderita Kanker". Hasil yang di dapat adalah art therapy sebagai intervensi yang bertujuan untuk mendukung proses penyembuhan, dapat ditarik kesimpulan bahwa art therapy dapat mengurangi kecemasan pada penderita kanker.

Pada jurnal "Art Therapy Seni Lukis Ekspresif Untuk Penderita Gangguan Kejiwaan Di Unit Informasi Layanan Sosial (UILS) Meruya” (Maftukha, 2017). Didapatkan hasil art therapy mampu sebagai katarsis atau saluran pembuangan energi negatif untuk mengatasi tekanan hidup pada penyandang gangguan kejiwaan (psikotik).

\section{Kesimpulan}

Berdasarkan hasil di atas dapat disimpulkan bahwa art therapy dan psikoedukasi keluarga efektif untuk menurunkan tingkat kecemasan pada remaja, baik kecemasan akademik atau lainnya. Hal ini dapat diketahui dari perubahan tingkah laku sebelum dan sesudah dilakukan intervensi serta dari hasil wawancara dengan orang tua dan guru klien. Klien dapat mengkomunikasikan apa yang ia rasakan, baik secara langsung ataupun melalui media gambar/lukis. Melalui katarsis yang dilakukan kecemasan yang dialami klien berkurang, sehingga menjadi lebih tenang ketika akan menghadapi ujian atau atau pelajaran disekolahnya. 


\section{BIBLIOGRAFI}

Adriani, Shinta Natalia, \& Satiadarma, Monty. (2011). Efektivitas art therapy dalam mengurangi kecemasan pada remaja pasien leukemia. Indonesian Journal of Cancer, 5(1).Google Scholar

Annisa, Dona Fitri, \& Ifdil, Ifdil. (2016). Konsep kecemasan (anxiety) pada lanjut usia (lansia). Konselor, 5(2), 93-99. .Google Scholar

Attri, A. K. (2013). Neelam. Academic anxiety and achievement of secondary school students-A study on gender differences. Int J Behav Soc Mov Sci, 2, 27-32. .Google Scholar

Blackburn, Ivy Marie, Davidson, K., \& Kendell, R. E. (1994). Terapi kognitif untuk depresi dan kecemasan suatu petunjuk bagi praktisi. Alih Bahasa: Rusda Koto Sutadi. Semarang: IKIP Semarang Press. .Google Scholar

Case, Caroline, \& Dalley, Tessa. (2002). Working with children in art therapy. Routledge. .Google Scholar

Dinie, Ratri Desiningrum. (2016). Terapi senam otak untuk menstimulasi kemampuan memori jangka pendek pada anak autis. Jurnal Psikologi, 43(1), 30-41. .Google Scholar

Edwards, David. (2014). Art therapy. sage. .Google Scholar

Ernawati, Lilis, \& Rusmawati, Diana. (2015). Dukungan sosial orang tua dan stres akademik pada siswa smk yang menggunakan kurikulum 2013. Jurnal Empati, 4(4), 26-31. .Google Scholar

Gussak, David. (2009). Comparing the effectiveness of art therapy on depression and locus of control of male and female inmates. The Arts in Psychotherapy, 36(4), 202-207. .Google Scholar

Hasanat, Nida Ul. (2016). Kajian Teoritis Pengaruh Art Therapy Dalam Mengurangi Kecemasan Pada Penderita. Buletin Psikologi, 18(1), 29-35. https://doi.org/10.22146/bpsi.11535.Google Scholar

Hughes, Joe. (2009). Deleuze's' Difference and Repetition': A Reader's Guide. Bloomsbury Publishing. .Google Scholar

Huss, Anke, Scott, Pippa, Stuck, Andreas E., Trotter, Caroline, \& Egger, Matthias. (2009). Efficacy of pneumococcal vaccination in adults: a meta-analysis. Cmaj, 180(1), 48-58. .Google Scholar

Maftukha, Nina. (2017). Art Therapy Seni Lukis Ekspresif untuk Penderita Gangguan Kejiwaan di Unit Informasi Layanan Sosial (Uils) Meruya. Narada, 4(3), 325-333. .Google Scholar 
Efektivitas Art Therapy Sebagai Katarsis untuk Mengurangi Tingkat Kecemasan Akademik pada Remaja

Malchiodi, Cathy. (2014). Breaking the silence: Art therapy with children from violent homes. Routledge. .Google Scholar

Mukhlis, Akhmad. (2011). Pengaruh terapi membatik terhadap depresi pada narapidana. Psikoislamika: Jurnal Psikologi Dan Psikologi Islam, 8(1).Google Scholar

Muthmainnah. (2015). Peranan Terapi Menggambar Sebagai Katarsis Emosi Anak. Jurnal Pendidikan Anak, 4(1). .Google Scholar

Puspitasari, Widya. (2013). Hubungan antara manajemen waktu dan dukungan sosial dengan prestasi akademik mahasiswa yang bekerja. EMPATHY Jurnal Fakultas Psikologi, 2(1), 1-17. .Google Scholar

Sholihah, Isna Ni'matus. (2018). Kajian teoritis penggunaan art therapy dalam pelaksanaan layanan bimbingan dan konseling di SMK. 1st ASEAN School Counselor Conference on Innovation and Creativity in Counseling. Ikatan Bimbingan dan Konseling Sekolah. .Google Scholar

Siswoyo, Siswoyo, Setioputro, Baskoro, \& Albarizi, Cholil. (2016). Psychoeducation Therapy Reduces Family Anxiety in Treating Family Member Who Suffers From Cataract. NurseLine Journal, 1(2), 237-245. .Google Scholar

Wallin, Ken, \& Durr, Marguerite. (2002). Creativity and expressive arts in social emotional learning. Reclaiming Children and Youth, 11(1), 30. .Google Scholar

Wu, Chunlei, Orozco, Camilo, Boyer, Jason, Leglise, Marc, Goodale, James, Batalov, Serge, Hodge, Christopher L., Haase, James, Janes, Jeff, \& Huss, Jon W. (2009). BioGPS: an extensible and customizable portal for querying and organizing gene annotation resources. Genome Biology, 10(11), 1-8. .Google Scholar

Wuryani, Sri Esti. (2016). Konseling dan terapi dengan anak dan orang tua. Google Scholar

\section{Copyright holder:}

Gusti Ayu Nyoman Triana Dewi, Tatik Meiyutariningsih (2021)

First publication right:

Syntax Literate: Jurnal Ilmiah Indonesia

This article is licensed under:

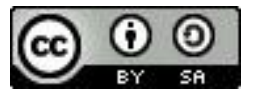

